\title{
KEBIJAKAN HUKUM PIDANA (PENAL) DAN NON HUKUM PIDANA (NON PENAL) DALAM MENANGGULANGI ALIRAN SESAT
}

\author{
SAIFUL ABDULLAH, SH
}

\begin{abstract}
ABSTRAK
Meningkatnya masalah-masalah kejahatan dan kekerasan yang berlatar belakang agama dan kepercayaan, terutama mengenai aliran sesat sampai saat ini dinilai sangat meresahkan, dan menghawatirkan, yang jika tidak ditanggulangi, dihawatirkan akan menimbulkan perpecahan di kalangan anggota keluarga dan masyarakat, bahkan kehidupan berbangsa dan bernegara.

Bertolak dari hal tersebut diatas, subtansi permasalahannya ada dua , yaitu kebijakan hukum pidana dalam menanggulangi aliran sesat untuk saat ini dan untuk saat yang akan datang maupun kebijakan non penal dalam menanggulangi aliran sesat. Dua permasalahan pokok ini pada intinya ditujukan untuk mengetahui dan menganalisa kebijakan hukum pidana dalam menanggulangi aliran sesat untuk saat ini dan untuk masa yang akan datang, maupun untuk mengetahui dan menganalisa kebijakan non penal dalam menanggulangi aliran sesat

Penelitian ini dilaksanakan dengan menggunakan metode deskriptif analitis dengan pendekatan yuridis normatif dan yuridis empiris. Pendekatan yuridis normatif digunakan untuk mengetahui sejauh mana asas-asas hukum, sinkronisasi vertikal/ horisontal, dan sistemik hukum diterapkan. Sedangkan, pendekatan yuridis empiris pada prinsipnya hukum dikonsepsikan secara sosiologis sebagai gejala empiris yang dapat diamati dalam kehidupan secara empiris yang teramati dalam pengalaman.

Dari hasil penelitian di dapat bahwa saat ini maka kebijakan penanggulangan aliran sesat dapat dilakukan dengan menggunakan hukum pidana (penal) dengan menggunakan Kitab Undang-undang Hukum Pidana (KUHP) maupun undang-undang di luar KUHP, terutama UU No 1 Pnps 1965. Sedangkan upaya antisipatif di masa yang akan datang dapat dilakukan dengan antisipasi yuridis, yaitu mempersiapkan berbagai peraturan yang bersangkut-paut dengannya. Sedangkan upaya non penal dapat ditempuh dengan melakukan pendekatan agama, budaya/kultural, moral/edukatif sebagai upaya preventif dengan melakukan serangkaian program kegiatan dengan fokus pengkuatan, penanaman nilai budi pekerti yang luhur, etika sosial, serta pemantapan keyakinan terhadap agama melalui pendidikan agama.

Konsepsi kebijakan penanggulangan aliran sesat adalah mengintegrasikan dan mengharmonisasikan kegiatan atau kebijakan non penal dan penal itu ke arah penekanan atau pengurangan faktor-faktor potensial untuk tumbuh dan suburnya aliran sesat di Indonesia. Dengan pendekatan integral inilah diharapkan , ummat dapat hidup berampingan secara damai dalam menjalankan agama, keyakinan,
\end{abstract}


ibadah dan kepercayaannya sebagaimana dicantumkan dalam Undang-undang Dasar 1945.

Kata Kunci: Aliran Sesat, Kebijakan Hukum Pidana (penal) dan Kebijakan Non Hukum Pidana (non penal)

\section{A. PENDAHULUAN}

\section{A.1. Latar Belakang}

Kebebasan beragama dan menjalankan agama di Indonesia sepenuhnya dijamin oleh undang-undang. Namun demikian, sepanjang sejarah keberagaman hidup dan pemikiran manusia dalam beragama, hampir bisa dipastikan terdapat sekelompok orang maupun perorangan yang memiliki ritual-ritual menyimpang atau nyeleneh dari agama yang dianutnya. Akibatnya, selalu ada pihak yang dinyatakan salah, sesat menyimpang dan keluar dari rel keagamaan umum. Puncaknya, sebagian masyarakat yang tidak puas, melakukan tindakan main hakim sendiri berupa serangkaian tindakan anarkis seperti eksekusi paksa massa, pengrusakan, pembakaran sarana fasilitas ibadah dan tindakan kekerasan lainnya.

Majelis Ulama Indonesia (MUI) selaku lembaga pemegang otoritas atas tafsir agama di Indonesia, mengeluarkan fatwa dan daftar aliran kepercayaan yang dianggap sesat dan menyesatkan, ${ }^{1}$ diantara aliran yang dianggap menyesatkan itu antara lain Islam Jamaah, Ahmadiyah, Ikrar Sunah, Qur'an Suci, Sholat Dua Bahasa, dan Lia Eden, ${ }^{2}$ sehingga yang bersangkutan didakwa melanggar pasal 156 KUHP dan pasal 157 KUHP. $^{3}$

Walaupun di antara pemimpin sekte atau aliran yang dituduh sesat diadili dan diberi sangsi pidana dengan tuduhan melakukan penodaan, penyimpangan agama, namun pengikutnya masih tetap patuh dan setia.

\footnotetext{
${ }^{1}$ Jawa Pos, Pelarangan Al-Qiyadah. 31 Oktober 2007 hal 4

2 TEMPO Interaktif, Jakarta 02 November 2007 | 23:45 WIB

3 A. Yogaswara, Maulana Ahmad jalidu, Aliran Sesat dan Nabi-nabi Palsu, Narasi, Yogyakarta 2008, hal 93
} 
Bahkan selepas dari penjara, yang bersangkutan tetap bertekad melanjutkan ajaran dan keyakinan bersama komunitasnya. ${ }^{4}$

Kajian mendalam untuk setiap langkah kebijakan, terutama menyangkut kebijakan hukum pidana (Penal) dan kebijakan non hukum pidana (non penal) terhadap aliran sesat sebagai bagian dari masalah-masalah "agama" dan "kehidupan/ berhubungan dengan agama" mutlak diperlukan. Karena bagaimanapun juga kajian ini pada akhirnya diharapkan bisa memberikan kontribusi dan bermanfaat bagi kerukunan hidup beragama berdampingan secara damai dalam rangka menopang pencapaian cita hukum dan tujuan bangsa sebagaimana dinyatakan dalam pembukaan Undang-undang Dasar 1945.

\section{A.2. Rumusan Masalah}

Bertolak dari latar belakang diatas, subtansi permasalahan yang akan dibahas adalah sebagai berikut:

1. Bagaimanakah kebijakan hukum pidana dalam menanggulangi aliran sesat untuk saat ini dan untuk saat yang akan datang?

2. Bagaimanakah kebijakan non penal dalam menanggulangi aliran sesat?

\section{A.3. Tujuan Penelitian}

Penelitian ini bertujuan untuk memberikan gambaran serta pemahaman sebagai berikut:

1. untuk mengetahui dan menganalisa kebijakan hukum pidana dalam menanggulangi aliran sesat untuk saat ini dan untuk masa yang akan datang.

2. untuk mengetahui dan menganalisa kebijakan non penal dalam menanggulangi aliran sesat

${ }^{4}$ M. Yuanda Zara et al, Aliran-aliran Sesat di Indonesia, Banyu Media, Yogyakarta, 2007 hal 45 


\section{A.4. Tinjauan Pustaka}

Kalau ilmu pengetahuan didefinisikan sebagai institusi pencarian kebenaran, maka pada waktu yang sama harus dikatakan bahwa pencarian kebenaran itu adalah proses yang dramatis. Ilmu pengetahuan memang berburu kebenaran, tetapi sekaligus juga disadari, bahwa kebenaran itu sendiri, kebenaran absolut, tidak pernah akan ditemukan. Memang suatu yang tragis, tetapi benar, karena hanya Allah tempat kebenaran yang sempurna. ${ }^{5}$

Bertolak dari hal tersebut di atas, dalam rangka menanggulangi aliran sesat yang semakin marak terjadi di Indonesia akhir-akhir ini, diperlukan suatu ilmu yang dapat memberi solusi antisipatif dalam rangka mencegah terjadinya kerusuhan maupun ketidak stabilan sosial, sehingga tujuan bangsa sebagaimana termaktub dalam pembukaan Undang-undang Dasar 1945 dan pembangunan nasional tidak terhambat.

Soedarto $^{6}$ menyatakan, bahwa apabila hukum pidana hendak dilibatkan dalam usaha-usaha mengatasi segi negatif perkembangan masyarakat, maka hendaknya dilihat dalam hubungan keseluruhan politik kriminal atau social defense planning. Selanjutnya social defense planning ini harus merupakan bagian intergral dari rencana pembangunan nasional.

Sehubungan dengan hal tersebut $\mathrm{di}$ atas, Oemar Senoadji mengemukakan tiga teori mengenai delik agama, yaitu; ${ }^{7}$

1. Friedensschutz Theorie, yaitu yang memandang ketertiban/ ketentraman umum sebagai kepentingan hukum yang dilindungi

2. Gefuhlsschutz Theorie, yaitu teori yang memandang rasa keagamaan sebagai kepentingan hukum yang harus dilindungi

3. Religionsschutz Theorie, yaitu teori yang memandang agama itu ansich sebagai kepentingan hukum yang harus dilindungi/ diamankan oleh negara

Teori di atas, secara tidak langsung memberikan sinyal bahwa harus ada paradigma baru, cara pandang baru dan kebijakan secara menyeluruh,

\footnotetext{
${ }^{5}$ Satjipto Rahardjo, Pidato mengakhiri masa jabatan sebagai Guru Besar Tetap pada Fakultas Hukum Universitas Diponegoro, 15 Desember 2000, hal11

${ }^{6}$ Barda Nawawi Arief, Kebijakan legislatif dalam Penanggulangan Kejahatan dengan Pidana Penjara, Badan Penerbit Universitas Diponegoro.Semarang. 2000.hlm 32

${ }^{7}$ Oemar Senoadji, Hukum (Acara) Pidana Dalam Prospeksi. Erlangga, Jakarta 1976 hal 75
} 
terutama kebijakan kriminal yang harus segera ditempuh oleh negara dalam menyelesaikan berbagai masalah, terutama aliran sesat ini

G P. Hoefnagels ${ }^{8}$ menguraikan beberapa upaya penanggulangan kejahatan, yaitu; penerapan hukum pidana (criminal law application); pencegahan tanpa pidana (prevention without punishment);mempengaruhi pandangan masyarakat tentang kejahatan ; dan pemidanaan melalui media masa ( influencing views of society on crime and punishment/mass media)

Berdasarkan pendapat G P. Hoefnagels diatas dapat disimpulkan bahwa Penanggulangan kejahatan (termasuk aliran sesat) secara umum dapat ditempuh melalui dua pendekatan yaitu penal dan non penal. Keduanya dalam fungsinya harus berjalan beriringan secara sinergis, saling melengkapi.

Jika pendekatan pertama yang ditempuh, maka ini berarti bahwa penanggulangan suatu kejahatan dilakukan dengan menggunakan kebijakan hukum pidana (penal policy/criminal law policy/strafrechtspolitiek), yaitu, "usaha mewujudkan peraturan perundang-undangan pidana yang sesuai dengan keadaan dan situasi pada suatu waktu dan untuk masa yang akan datang" 9. Artinya, hukum pidana difungsikan sebagai sarana pengendali sosial, yaitu dengan sanksinya yang berupa pidana untuk dijadikan sarana menanggulangi kejahatan. Dengan demikian diharapkan norma-norma sosial dapat ditegakkan dengan sanksi yang dimiliki hukum pidana terhadap seseorang yang berperilaku tidak sesuai dengan norma-norma tersebut.

Apabila dilihat dari sudut kebijakan kriminal, upaya penanggulangan aliran sesat dengan menggunakan sarana penal bukan kebijakan yang strategis, karena kebijakan mempunyai keterbatasan dan mengandung beberapa kelemahan (sisi-sisi negatif). Jadi, jika dilihat dari sudut kebijakan, maka penggunaan atau intervensi penal seyogyanya dilakukan dengan lebih hatihati, cermat, hemat, selektif dan limitatif. ${ }^{10} \mathrm{Hal}$ ini penting dilakukan dalam

\footnotetext{
${ }^{8}$ Barda Nawawi Arief. Bunga Rampai Kebijakan Hukum Pidana, Citra Aditya Bakti, Bandung: 2002. hal 1

${ }^{9}$ Ibid. hal 28. Dalam hal ini marc Ancel mendefinisikan penal policy sebagai "suatu ilmu sekaligus seni yang bertujuan untuk memungkinkan peraturan hukum positif (dalam hal ini hukum pidana ) dirumuskan secara lebih baik"

${ }^{10} \mathrm{Ibid}$, hal 48
} 
rangka memaksimalkan upaya pencegahan kejahatan dalam masyarakat karena sumber/penyebab terjadinya perilaku meyimpang, terutama dalam kehidupan beragama sangat komplek, dan jika hanya bertumpu pada hukum pidana/ penal tentu belum cukup.

Berdasarkan hal-hal tersebut diatas, dilihat dari sudut "criminal policy", upaya penanggulangan kejahatan (termasuk penanggulangan aliran sesat) tentunya tidak dapat dilakukan secara parsial dengan hukum pidana (sarana "penal"), tetapi harus ditempuh pula dengan pendekatan integral/sistemik. Dengan demikian, jika Aliran sesat ini diasumsikan/ dipersamakan sebagai bagian dari "tindak pidana terhadap agama dan tindak pidana yang berhubungan dengan agama”, maka adalah wajar jika upaya penanggulangannya ditempuh melalui pendekatan agama (religion Approach) di samping pendekatan budaya/kultural, pendekatan moral/edukatif, dan lain sebagainya.

\section{A.5. Metode Penelitian}

Penelitian ini dilaksanakan dengan menggunakan metode deskriptif analitis dengan pendekatan yuridis normatif dan yuridis empiris. ${ }^{11}$ Pendekatan yuridis normatif digunakan untuk mengetahui sejauh mana asas-asas hukum, sinkronisasi vertikal/ horisontal, dan sistemik hukum diterapkan. Pendekatan yuridis empiris dalam perspektif Soetandyo Wigjosoebroto, pada prinsipnya hukum dikonsepsikan secara sosiologis sebagai gejala empiris yang dapat diamati dalam kehidupan secara empiris yang teramati dalam pengalaman. ${ }^{12}$ Untuk memudahkan penelusuran data maka dapat di gunakan pendekatan penegakan hukum berdasarkan pada faktor-faktor yang mempengaruhinya. ${ }^{13}$

11 Pendekatan demikian dapat pula disebut pendekatan doctrinal atau yang biasa disebut pendekatan normative dan pendekatan non doctrinal atau yang biasa disebut dengan pendekatan empirik.Lihat Kamri Ahmad, Peranan Masyarakat dalam penyelesaian Tindak Pidana Di Sulawesi Selatan, Ringkasan Desertasi, disampaikan pada Rapat Senat Terbatas Ujian Doktor Dalam Ilmu Hukum pada Program Doktor Ilmu Hukum Undip, tanggal 30 Mei 2007, hal 16

12 Lihat, Soetandyo Wigjosoebroto, Hukum: Paradigma, Metode dan Dinamika Masalahnya, ELSAM HUMA, Jakarta 2002, hal 146

${ }^{13}$ Soerjono Soekanto, Faktor-faktor yang Mempengaruhi Penegakan Hukum, PT. Raja Grafindo Perkasa, , Jakarta, 1993; 


\section{B. HASIL PENELITIAN DAN PEMBAHASAN}

\section{B.1. Kebijakan Hukum Pidana (Penal) Terhadap Aliran Sesat}

\section{B.1.1. Kebijakan Hukum Pidana Saat Ini}

KUHP sebagai dasar-dasar dan aturan-aturan untuk menentukan perbuatan-perbuatan mana yang tidak boleh dilakukan, memiliki tujuantujuan sebagaimana tujuan hukum pada umumnya. Arti terpenting dari adanya hukum pidana sebagai bagian dari sistem hukum yang berlaku di dalam suatu negara, terletak pada tujuan hukum pidana itu sendiri yakni menciptakan tata tertib di dalam masyarakat sehingga kehidupan masyarakat dapat berlangsung dengan damai dan tenteram. ${ }^{14}$

Ajaran moderen berpendapat, bahwa tujuan hukum pidana adalah untuk melindungi masyarakat terhadap kejahatan, ${ }^{15}$ di samping tujuan-tujuan lainnya. ${ }^{16}$ Artinya masyarakat perlu memperoleh perlindungan dengan jelas, tersirat, hukuman-hukuman apa yang dapat dijatuhkan kepada pelanggar ketertiban baik yang membahayakan jiwa, harta benda atau kepentingan masyarakat lainnya, termasuk kepentingan dalam kehidupan beragama.

Jadi, kebijakan penal (hukum pidana) pada hakikatnya mengandung unsur preventif, karena dengan adanya ancaman dan penjatuhan pidana terhadap delik/ kejahatan diharapkan adanya efek pencegahan/ penangkalnya.

${ }^{14}$ Untuk menjamin pergesekan kepentingan itu tidak menjadi konflik berkepanjangan, maka dibuatlah aturan-aturan (hukum) tertentu (di antaranya dikenal dengan hukum pidana), baik dibuat secara sepihak maupun dibuat bersama-sama sebagai hasil kesepakatan bersama, untuk mempertahankan kedamaian dan kesejahteraan. lihat Jhon Gilissen dan Firts Gorle, Sejarah Hukum Suatu Pengantar, edisi terjemahan, Refika Aditama, Bandung, 2005, hal 42-43

${ }^{15}$ lihat Lili Rasjidi, Dasar Dasar Filsafat Hukum, Citra Aditya Bakti,Bandung, 1990 hal 65

${ }^{16}$ Hukum pidana sebagai bagian dari sistem hukum yang berlaku di dalam suatu negara memiliki makna penting sebagaimana tujuan hukum pada umumnya, yaitu menciptakan tata tertib di dalam masyarakat sehingga kehidupan masyarakat dapat berlangsung dengan damai dan tenteram. Ajaran moderen berpendapat bahwa tujuan hukum pidana adalah untuk melindungi masyarakat dari kejahatan. Masyarakat perlu memperoleh perlindungan dengan jelas, tersirat, apa yang dapat dijatuhkan kepada pelanggar ketertiban. Lihat Lili Rasjidi, 1990. ibid hal 65 
Hal ini berarti, bahwa hukum pidana difungsikan sebagai sarana pengendali sosial, yaitu dengan sanksinya yang berupa pidana untuk dijadikan sarana menanggulangi kejahatan.

Selain itu, kebijakan penal tetap diperlukan dalam penanggulangan aliran sesat, karena hukum pidana merupakan salah satu sarana kebijakan sosial untuk menyalurkan "ketidak sukaan masyarakat (Social dislike) atau pencelaan/ kebencian sosial (Social disapproval/ Social abhorrence) yang sekaligus juga diharapkan menjadi sarana perlindungan sosial (Social defence). Oleh karena itu sering dikatakan bahwa "Penal policy" merupakan bagian dari kebijakan perlindungan sosial (Social Defence Policy) yang memiliki sifat universal di semua negara. ${ }^{17}$

Patut dicatat, digunakannya hukum pidana sebagai sarana untuk menanggulangi kejahatan, selama ini masih merupakan sesuatu yang lazim digunakan di berbagai negara, termasuk Indonesia. Hal ini terlihat dari praktik perundang-undangan selama ini menunjukkan, bahwa penggunaan hukum pidana merupakan bagian dari kebijakan atau politik hukum yang dianut di Indonesia.

Oleh karena itu, dengan diformulasikannya delik-delik agama dalam berbagai aturan, terutama dalam Kitab Undang-undang Hukum Pidana (KUHP) sebagai tindak pidana, berarti merupakan kebijakan penal, yaitu usaha rasional dalam menanggulangi kejahatan tindak pidana dengan menggunakan sarana penal (hukum pidana), merupakan bagian dari kebijakan kriminal (criminal policy) dalam melindungi masyarakat dari kejahatan, serta merupakan bagian dari kebijakan sosial untuk mencapai tujuan nasional sebagaimana terdapat dalam pembukaan UUD 1945.

\footnotetext{
${ }^{17}$ Menurut Soedarto, kebijakan penanggulangan kejahatan dengan menggunakan sarana penal (hukum pidana), harus memperhatikan tujuan pembangunan nasional, yaitu mewujudkan masyarakat adil dan makmur yang merata materiel spiritual berdasarkan Pancasila. Sehubungan dengan ini maka (penggunaan) hukum pidana bertujuan untuk menanggulangi kejahatan dan mengadakan pengugeran terhadap tindakan penanggulangan itu sendiri, demi kesejahteraan dan pengayoman masyarakat Barda Nawawi Arief, Kebijakan Legislatif dalam Penanggulangan Kejahatan dengan Pidana Penjara, Badan Penerbit Universitas Dipoegoro, Semarang 1996 hal $35-36$
} 
Secara singkat, dalam perspektif hukum pidana, aliran sesat merupakan bagian dari cakupan delik-delik agama, dan merupakan bagian dari tindak pidana terhadap ketertiban umum sebagaimana delik-delik agama dalam UU No 1 Pnps 1965, dan Pasal 156 a KUHP. Pada posisi inilah, negara ${ }^{18}$ memiliki kewajiban untuk mengatur, melarang, mengawasi, menanggulangi dan seterusnya terhadap aliran sesat atas nama perlindungan masyarakat maupun

\section{ketertiban umum.}

Bertolak dari hal-hal tersebut di atas, kebijakan hukum pidana dalam menanggulangi aliran sesat untuk saat ini terurai sebagai berikut;

1. Secara filosofis, perlindungan terhadap agama maupun dan kehidupan beragama sebagaimana terdapat dalam substansi (ruh dan semangat) KUHP dan UU No 1 Pnps 1965 merupakan kebijakan yang sangat rasional. Dikatakan sangat rasional mengingat masyarakat Indonesia adalah masyarakat agamis yang menghendaki agar Kitab Undang-Undang Hukum Pidana yang dimiliki bangsa Indonesia itu seberapa dapat harus menyerap nilai-nilai hukum agama sebagai konsekuensi logis dari sebuah bangsa dan negara yang mengaku diri religius.

2. Selain hal tersebut di atas tentu saja sangat Pancasilais dan benar-benar sah menurut hukum. Sebab, seperti diketahui, Pancasila terutama sila pertamanya -Ketuhanan Yang maha Esa - memberikan landasan/ asas yang sangat kokoh bagi setiap pembangunan peradaban dan kebudayaan yang ingin ditegakkan di bumi Indonesia.

3. Negara RI yang berdasarkan Ke-Tuhanan Yang Maha Esa tidak saja meletakkan dasar moral di atas negara dan pemerintah, tetapi juga memastikan adanya kesatuan nasional yang berasas keagamaan. Pengakuan tersebut tidak dapat dipisah-pisahkan dengan agama karena salah satu yang pokok dari kehidupan manusia dan bagi bangsa Indonesia

\footnotetext{
${ }^{18}$ Menurut Yusril Ihza Mahendra, negara memiliki hak untuk memaksakan hukum demi tercapainya tata tertib dalam masyarakat. "Pro Kontra Syariat Islam" Debat Publik TV One 16 Juli 2008. 19.00
} 
adalah juga sebagai sendi kehidupan negara dan unsur mutlak dalam usaha membangun negara.

4. Landasan/ asas teologis ini semakin memperoleh bentuk konkret dalam Pasal 29 Undang-Undang Dasar 1945 yang menyatakan: (1) "Negara berdasar atas Ketuhanan Yang Maha Esa." (2) "Negara menjamin kemerdekaan tiap-tiap penduduk untuk memeluk agamanya masingmasing dan untuk beribadat menurut agamanya dan kepercayaanya itu“. ${ }^{19}$

Uraian di atas dapat ditegaskan, bahwa dilihat dari aspek idiel (Pancasila) dan Konstitusionil (Pasal 29 Undang-Undang Dasar 1945), maka agama merupakan kepentingan hukum yang harus dilindungi, hal ini merupakan sebuah konsekuensi logis dari adanya sila pertama Pancasila "Ketuhanan Yang Maha Esa" yang tidak bisa dipisahkan dengan agama, sebagai landasan moral dan landasan kesatuan nasional. ${ }^{20}$

Berdasarkan hal tersebut di atas, maka adalah wajar dan sepatutnya jika perlindungan terhadap agama dituangkan dalam perangkat hukum yang menjamin, melindungi agama dari perbuatan penyimpangan dan menodai agama bahkan ajaran-ajaran untuk tidak memeluk agama yang banyak menimbulkan bahaya bagi persatuan nasional dan bahaya bagi agama serta ketentraman beragama.

Selain itu, agama dalam kehidupan dan kenyataan hukum di Indonesia merupakan faktor fundamental, dapatlah dimengerti apabila "perlindungan terhadap agama" diformulasikan dalam berbagai produk perundang-undangan di Indonesia. Hal demikian merupakan konsekuensi logis dari adanya asaz fundamental pengaturan berbangsa dan bernegara yang menegaskan," Indonesia ialah Negara yang berdasarkan hukum".

\footnotetext{
${ }^{19}$ Muh. Amin Suma, Telaah Kritis Sumbangan Konstruktif Terhadap RUU KUHP, Makalah, Disampaikan pada "Sosialisasi Rancangan Undang-Undang Kitab Undang-Undang Hukum Pidana " diselenggarakan oleh Departemen Kehakiman dan HAM Direktorat Jenderal Peraturan Perundang-undangan Jakarta, 08 September 2004, hal 2

${ }^{20}$ Pancasila hakikatnya mengandung nilai-nilai kesusilaan/kesepakatan nasional, yang di dalamnya antara lain mengandung nilai-nilai berkehidupan kebangsaan yang didasarkan pada nilai-nilai Ketuhanan Yang Maha Esa, kemanusiaan yang adil dan beradap, persatuan Indonesia dan seterusnya.
} 
Kenyataan-kenyataan sebagaimana diuraikan sebelumnya menunjukkan, bahwa dari sekian banyak praktek perbuatan yang dilakukan oleh aliran keagamaan/ kepercayaan tertentu justru banyak yang bertentangan dengan hukum yang berlaku di Indonesia (khususnya delik-delik agama), bertentangan dengan nilai-nilai yang berlaku dalam masyarakat yang menyebabkan terganggunya perasaan tertib dan tentramnya suatu masyarakat, ${ }^{21}$ dan bahkan dapat memicu terjadinya disintegrasi bangsa dan lain sebagainya.

Patut dicatat, ketika keberadaan suatu aliran kepercayaan masyarakat ternyata perbuatannya melewati batas tertentu, misalnya saja mengarah pada perbuatan kriminal, membahayakan ketertiban umum, meresahkan masyarakat dan lain sebagainya, maka hubungan antar masyarakat umum dengan anggota aliran tertentu, dapat berubah menjadi hubungan yang tidak harmonis bahkan bisa jadi sampai ke tingkat kerisauan atau keresahan.

Bertolak dari hal-hal tersebut di atas, dilihat dari sudut kebijakan, maka kebijakan hukum pidana dalam menanggulangi (dengan menggunakan sarana penal, khususnya pasal 156a KUHP dan UU No 1 Pnps 195) aliran sesat ini, merupakan usaha yang sangat rasional dan mutlak diperlukan. Artinya, hukum pidana difungsikan sebagai sarana pengendali sosial, yaitu dengan sanksinya yang berupa pidana untuk dijadikan sarana menanggulangi kejahatan. Dengan demikian diharapkan norma-norma sosial dapat ditegakkan dengan sanksi yang dimiliki hukum pidana terhadap seseorang yang berperilaku tidak sesuai dengan norma-norma tersebut.

Selain itu, hukum pidana sebagai bagian dari sistem hukum yang berlaku di dalam suatu negara memiliki makna penting sebagaimana tujuan hukum pada umumnya, yaitu menciptakan tata tertib di dalam masyarakat sehingga kehidupan masyarakat dapat berlangsung dengan damai dan tenteram. ${ }^{22}$

\footnotetext{
${ }^{21}$ Lihat Barda Nawawi Arief, Kebijakan Kriminalisasi Kumpul Kebo Dan Santet, makalah pada Seminar "Relevansi KUHP Dalam Upaya Penegakan Supremasi Hukum di Indonesia" FH UNUD, 30 April 2005 hal 10-11

${ }^{22}$ Ajaran moderen berpendapat bahwa tujuan hukum pidana adalah untuk melindungi masyarakat dari kejahatan. Masyarakat perlu memperoleh perlindungan dengan jelas, tersirat, apa yang dapat dijatuhkan kepada pelanggar ketertiban. Lihat Lili Rasjidi, 1990. op.cit. hal 65
} 
Berdasarkan uraian di atas, kebijakan penanggulangan tindak pidana terhadap agama (termasuk terhadap aliran sesat) berarti hukum pidana difungsikan sebagai sarana pengendali sosial, yaitu dengan sanksinya yang berupa pidana dijadikan sarana menanggulangi kejahatan. Dengan demikian diharapkan norma-norma sosial dapat ditegakkan dengan sanksi yang dimiliki hukum pidana terhadap seseorang yang berperilaku tidak sesuai dengan norma-norma sosial yang telah diterima dan disepakati bersama, sehingga diharapkan pula terciptanya kehidupan yang rukun, damai dan tentram.

\section{B.1.2. Kebijakan Hukum Pidana Untuk Masa Yang Akan Datang}

Sebagaimana telah dimaklumi, digunakannya hukum pidana sebagai sarana untuk menanggulangi kejahatan, selama ini masih merupakan sesuatu yang lazim $^{23}$ digunakan di berbagai negara, termasuk Indonesia. Hal ini terlihat dari praktik perundang-undangan selama ini menunjukkan bahwa penggunaan hukum pidana merupakan bagian dari kebijakan atau politik hukum yang dianut di Indonesia.

Praktik selama ini menunjukkan, bahwa penggunaan hukum pidana merupakan sesuatu yang lazim digunakan dalam mencegah dan menanggulangi aliran sesat. Namun demikian patut dicatat, bahwa Produk legislatif yang ada saat ini masih jauh dari kata memadai, dalam hal ini delikdelik agama yang ada dalam $\mathrm{KUHP}^{24}$ maupun yang ada di luar KUHP,

23 H.L. Packer mengemukakan perlunya penggunaan (hukum) pidana -dengan segala keterbatasannya- sebagai sarana untuk menanggulangi kejahatan dengan alasan bahwa sanksi pidana sangatlah diperlukan; kita tidak dapat hidup sekarang maupun di masa yang akan datang, tanpa pidana. sanksi pidana merupakan alat atau sarana terbaik yang tersedia, yang kita miliki untuk menghadapi kejahatan-kejahatan atau bahaya besar dan segera serta untuk menghadapi ancamaman-ancaman dari bahaya. sanksi pidana merupakan 'penjamin yang utama/ terbaik' apabila digunakan secara hemat, cermat dan secara manusiawi. Pendapat senada dikemukakan Bassiouni, von liszt, A Print, van hammel dan sarjana-sarjana lainnya. Selengkapnya lihat, Barda Nawawi Arief, 1996, op.cit. hal155-156.

${ }^{24}$ Sampai saat ini dalam KUHP Indonesia warisan Belanda (Wvs) tidak ada "bab khusus" yang mengatur delik (terhadap) agama maupun delik yang berhubungan dengan agama. Dalam KUHP hanya ada "delik yang berhubungan dengan agama" yang ditempatkan sebagai bagian dari tindak pidana terhadap ketertiban umum. Walaupun dalam perkembangannya pada tahun 1965 ditambahkan delik penodaan agama ke dalam KUHP, namun tetap saja dimasukkan sebagai bagian dari tindak pidana terhadap ketertiban umum. Di dalam KUHP juga tidak ada perumusan 
khususnya UU No 1 Pnps 1965 sebagai sarana untuk menanggulangi masalahmasalah kejahatan ${ }^{25}$ berlatar belakang agama (aliran sesat) dianggap kurang memadai dan bahkan dianggap ketinggalan zaman, ${ }^{26}$ sehingga menimbulkan pro dan kontra di kalangan masyarakat luas.

Atas dasar hal tersebut, antisipasi yuridis terhadap aliran sesat (dengan mempersiapkan berbagai produk legislatif) dilatarbelakangi oleh kebutuhan dan tuntutan nasional untuk melakukan pembaharuan dan sekaligus perubahan/ penggantian. Jadi, antisipasi yuridis terhadap aliran sesat berkaitan erat dengan ide "penal reform" (pemba-haruan hukum pidana) yang pada hakikatnya juga merupakan bagian dari ide yang lebih besar, yaitu pembangunan/pembaharuan (sistem) hukum nasional.

Antisipasi yuridis dengan cara menyiapkan produk perundang-undangan (melakukan pembaharuan hukum) mengenai aliran sesat pada hakikatnya termasuk bidang "penal policy" yang merupakan bagian dan terkait erat dengan "law enforcement policy", "criminal policy”, dan "social policy”.

Bertolak dari pemikiran di atas, maka antisipasi yuridis dengan cara mempersiapkan berbagai produk legislatif mengenai aliran sesat sebagai bagian dari cakupan delik-delik agama di masa yang akan datang, sepatutnya berorientasi pada pendekatan yang berorientasi pada kebijakan (“policy oriented approach”) dan sekaligus pendekatan yang berorientasi pada nilai (“value oriented approach"), ${ }^{27}$ agar hukum pidana (khususnya delik-delik

secara tegas mengenai delik penghinaan terhadap Tuhan (Blasphemy/Godslastering), apalagi delik mengenai "aliran sesat".

${ }^{25}$ Kitab Undang-undang Hukum Pidana (KUHP) sebagai sarana pengendalian sosial, yaitu dengan sanksinya dijadikan sebagai sarana penanggulangan kejahatan, khususnya untuk mengatur dan memelihara ketentraman antar dan intra umat beragama

${ }^{26}$ Kongres-kongres PBB mengenai "The Prevention of Crime and the Treatment of Offenders" sering menyatakan dan mensinyalir, bahwa sistem hukum pidana yang ada selama ini di beberapa negara, berasal (diimpor) dari hukum asing semasa zaman kolonial, pada umumnya telah usang dan tidak adil ("obsolete and unjust") serta sudah ketinggalan zaman dan tidak sesuai dengan kenyataan ("outmoded and unreal") karena tidak berakar pada nilai-nilai budaya dan bahkan ada "diskrepansi" dengan aspirasi masyarakat serta "tidak responsif" terhadap kebutuhan sosial masa kini. Lihat Barda Nawawi Arief, Beberapa Aspek Kebijakan Penegakan dan Pengembangan Hukum Pidana, PT. Citra Aditya Bakti, Bandung, 1998, halaman 102

${ }^{27}$ Jelasnya, sesuai dengan nilai-nilai Pancasila dan/ atau prinsip-prinsip hukum umum yang diakui oleh masyarakat bangsa-bangsa”. Jadi, pedoman/kriterianya bertolak dari nilai-nilai na-sional 
agama) bisa mencegah tindak pidana dan tidak menjadi sumber penyulut konflik antar umat beragama sekaligus faktor kriminogen baru di masyarakat.

Bertolak dari ide dasar di atas, antisipasi yuridis terhadap aliran sesat di masa yang akan datang kebijakan (terutama pembangunan substansi) hukum pidana pada dasarnya adalah untuk menegakkan nilai-nilai sosial dasar dalam aspek kehidupan religius, keagamaan masyarakat ditujukan untuk memelihara toleransi dan penghormatan harkat dan martabat manusia.

Pada akhirnya diharapkan dalam konteks ini difungsikan sebagai stabilisasi dan harmoni dalam kehidupan keagamaan masyarakat, karena keragamaan agama dan kepercayaan masyarakat tidak jarang menjadi sumber konflik, oleh karena itu berbagai tindakan, perbuatan yang mengancam aspek kehidupan keagamaan bahkan agama itu sendiri dianggap sebagai kepentingan hukum yang harus dilindungi.

Muladi dalam berbagai seminar menegaskan bahwa latar belakang kriminalisasi delik agama dalam RUU KUHP bukan semata-mata memangkas dan memberangus kebebasan beragama masyarakat, tetapi justru ditujukan untuk melindungi kebebasan umat beragama dalam menjalankan agama dan kepercayaan, serta melindungi agama Tuhan dan simbol-simbolnya dari kelompok-kelompok yang bermaksud menodai dan menistakannya. ${ }^{28}$

Dirumuskannya delik-delik agama dalam KUHP maupun Konsep KUHP, sesuai dengan tujuan asas legalitas, dimaksudkan sebagai upaya pencegahan (prevensi) atau peringatan bagi masyarakat, bahwa perbuatan

maupun internasional. Sesuai dengan nilai-nilai nasional (Pan-casila), artinya sesuai dengan nilai/paradigma moral religius, nilai/ paradigma kemanusiaan (humanis), nilai/paradigma kebangsaan, nilai/paradigma demokrasi (kerakyatan/hikmah kebijaksanaan), dan nilai/paradigma keadilan sosial. Lihat, Barda Nawawi Arief, Pembaharuan Hukum Pidana Dalam Perspektif Perbandingan, Citra Aditya Bakti, Bandung; 2005 hal 2 atau lihat pula Barda Nawawi Arief, Sistem Pemidanaan Dalam Ketentuan Umum Konsep RUU KUHP 2004, Bahan Sosialisasi RUU KUHP 2004, diselenggarakan oleh Departemen Hukum dan HAM, tgl. 23-24 Maret 2005, di Hotel Sahid Jakarta.

${ }^{28}$ Muladi. Politik Hukum Pidana, Dasar Kriminalisasi dan Dekriminalisasi serta Beberapa Perkembangan Asas dalam RUU KUHP. Makalah. Dalam Beberapa tulisan Terkait kebijakan Kriminal dalam RUU KUHP. Bahan Bacaan untuk Focus Group Discussion yang diselenggarakan ELSAM, DRSP (Democratic Reform Support Program) dan Aliansi Nasional Reformasi KUHP dengan tema: “Melihat Politik Kodifikasi dalam Rancangan KUHP”. Hotel Ibis Tamrin, Jakarta 28 September 2006 
penghinaan terhadap agama dan kehidupan beragama di Indonesia dilarang karena merupakan tindak pidana (criminal act). Dengan kata lain, agama dalam kehidupan dan kenyataan hukum kita merupakan faktor fundamental, dapatlah dimengerti apabila faktor tersebut digunakan sebagai landasan yang kuat dan kokoh dihidupkanya delik-delik agama.

Oleh karena itu, maka Konsep KUHP bukan semata-mata memangkas dan memberangus kebebasan beragama masyarakat, tetapi justru ditujukan untuk melindungi kebebasan umat beragama dalam menjalankan agama dan kepercayaan, serta melindungi agama Tuhan dan simbol-simbolnya dari kelompok-kelompok yang bermaksud menodai dan menistakannya.

Diformulasikannya delik-delik agama dalam Konsep KUHP harus diartikan sebagai keseriusan/ kesungguhan bangsa ini untuk berupaya memperbaiki dan melakukan pembaharuan terhadap hukum sekaligus sebagai wujud kebijakan antisipasi yuridis terhadap aliran sesat untuk masa yang akan datang. Pada posisi inilah diharapkan munculnya kesadaran bersama untuk saling menghormati, menghargai agama dan kehidupan beragama yang rukun, damai dan tentran di masa yang akan datang.

\section{B.2. Kebijakan Pendekatan Non Penal Terhadap Aliran Sesat}

Kongres-kongres PBB mengenai "the prevention of crime and the treatment of offenders menyatakan hal-hal sebagai berikut; ${ }^{29}$

Pencegahan kejahatan harus didasarkan pada penghapusan sebab-sebab dan kondisi-kondisi yang menyebabkan timbulnya kejahatan. Upaya penghapusan sebab-sebab dan kondisi-kondisi yang demikian harus merupakan "strategi pokok/mendasar dalam upaya pencegahan kejahatan" (the basic crime prevention strategy).

(- "Crime prevention strategies should be based upon the elimination of causes and conditions giving rise to crime"; - "The basic crime prevention strategy must consist in eliminating the causes and conditions that breed crime");

${ }^{29}$ dalam Barda Nawawi Arief, Pembaharuan Hukum Pidana Dalam Perspektif Perbandingan, Citra Aditya Bakti, Bandung; 2005 hal 77-78 
Bertolak dari kongres-kongres PBB mengenai "the prevention of crime and the treatment of offenders di atas, maka Pencegahan terhadap aliran sesat (sebagai kejahatan menurut UU No 1 Pnps 1965), sepatutnya harus didasarkan pada penghapusan sebab-sebab dan kondisi-kondisi yang menyebabkan timbulnya aliran sesat (kejahatan).

Upaya penggulangan aliran sesat melalui sarana non penal akan lebih mempunyai sifat pencegahan. Sehingga yang menjadi sasaran utama penanganannya adalah mengenai faktor-faktor penyebab terjadinya kejahatan. Fakto-faktor tersebut adalah yang ditujukan terhadap kondisi-kondisi sosial yang secara langsung maupun tidak langsung dapat menimbulkan munculnya aliranaliran sesat.

Sebagai salah satu bentuk dari "penyimpangan agama", adalah wajar upaya penanggulangan aliran sesat juga harus ditempuh dengan pendekatan agama (religion prevention). ${ }^{30} \mathrm{Di}$ samping itu diperlukan pula pendekatan budaya/kultural, pendekatan moral/edukatif karena diantara faktor-faktor penyebab munculnya aliran sesat juga terkait erat dengan budaya dan keawaman (pendidikan) penganutnya.

Salah satu kesimpulan dan rekomendasi (saran pemecahan masalah) Hasil Seminar Pembangunan Hukum Nasional VINII tahun 2003 di Kuta, Denpasar, Bali, ditegaskan antara lain : ${ }^{31}$

Menjadikan ajaran agama sebagai sumber motivasi, sumber inspirasi, dan sumber evaluasi yang kreatif dalam membangun insan hukum yang berakhlak mulia, sehingga wajib dikembangkan upaya-upaya konkret dalam muatan kebijakan pembangunan hukum nasional yang dapat :

- memperkuat landasan budaya keagamaan yang sudah berkembang dalam masyarakat;

- memfasilitasi perkembangan keberagamaan dalam masyarakat dengan kemajuan bangsa;

${ }^{30}$ Bandingkan dengan logika/ konsep Barda Nawawi Arief dalam konsep penanggulangan Cyber crime. Dalam konsep ini, menurut Barda Nawawi Arief, penanggulangan Cyber crime, harus ditempuh dengan pendekatan teknologi (karena cyber crime merupakan bagian dari penyalahgunaan/ penyimpangan dari tekhnologi, pen). Lihat Barda Nawawi Arief, Kebijakan Penanggulangan Cyber Crime Dan Cyber Sex, op.cit hal 11

${ }^{31}$ Lihat Rumusan Hasil Seminar Pembangunan Hukum Nasional VINII, angka INI sub B.7, termuat dalam Seminar Pembangunan Hukum Nasional VINII, Buku 1, BPHN Depkeh dan HAM, 2003, hal 7, selanjutnya lihat Barda Nawawi Arief, 2005. op.cit. hal 4 
- mencegah konflik sosial antar umat beragama dan meningkatkan ( "meningkatkan kerukunan") antar umat bangsa.

Berpijak pada hal-hal tersebut di atas, dengan mendasarkan pada agama, kongres $\mathrm{PBB}$ mengenai $\mathrm{PBB}$ mengenai "the prevention of crime and the treatment of offenders ${ }^{32}$, dan methode penanggulangan kejahatan sebagaimana konsep G P. Hoefnagels ${ }^{33}$, maupun pendapat-pendapat ilmiah lainnya, maka bentuk/ cara penanggulangan terhadap masalah aliran sesat/ perbedaan pandangan keagamaan melalui non penal yang bersifat preventif (pencegahan) dan kausatif (pengobatan).

Jadi, penanggulangan aliran sesat/ perbedaan pandangan keagamaan/ kepercayaan, dapat dilakukan dengan melakukan "pendekatan agama" sebagai sarana non penal. Atau dengan kata lain, pendekatan agama merupakan salah satu upaya non penal dalam menanggulangi aliran sesat perbedaan pandangan keagamaan/ kepercayaan. Sedangkan bentuk konkretnya berupa; Pendekatan Pendidikan/ edukatif maupun Pendekatan kultural dengan cara membangun komitmen bersama, dakwah, dialog, dan lain sebagainya

Selain itu, konsepsi kebijakan penanggulangan aliran sesat, sepatutnya dilakukan secara integral. Pendekatan demikian mengandung konsekuensi bahwa segala usaha yang rasional untuk menanggulangi aliran sesat harus merupakan satu kesatuan yang terpadu. Ini berarti kebijakan untuk menangulangi aliran sesat adalah mengintegrasikan dan mengharmonisasikan kegiatan atau kebijakan non penal dan penal itu ke arah penekanan atau pengurangan faktor-faktor potensial untuk tumbuh dan suburnya aliran sesat di Indonesia. Dengan pendekatan integral inilah diharapkan penanggulangan aliran sesat benar-benar dapat berhasil, sehingga ummat dapat hidup berampingan secara damai dalam menjalankan agama, keyakinan, ibadah dan kepercayaannya sebagaimana dicantumkan dalam Undang-undang Dasar 1945.

\footnotetext{
32 penghapusan sebab-sebab dan kondisi-kondisi yang menyebabkan timbulnya kejahatan, lihat Barda Nawawi Arief, 2005. op.cit. hal 77-78

33 pencegahan tanpa pidana (prevention without punishment), mempengaruhi pandangan masyarakat tentang kejahatan, dan pemidanaan melalui media masa ( influencing views of society on crime and punishment/mass media) Muladi, 1995.op.cit. hal. 48
} 


\section{PENUTUP}

\section{C.1. KESIMPULAN}

Berdasarkan uraian sebelumnya, dapat disimpulkan hal-hal sebagai berikut:

Pertama, Penanggulangan dengan menggunakan hukum pidana (penal), yaitu dengan menggunakan Kitab Undang-undang Hukum Pidana (KUHP) maupun undang-undang di luar KUHP, terutama UU No 1 Pnps 1965. Artinya, dengan menggunakan hukum pidana, maka hukum pidana difungsikan sebagai sarana pengendali sosial, yaitu dengan sanksinya yang berupa pidana dijadikan sarana menanggulangi kejahatan (aliran sesat). Dengan demikian diharapkan norma-norma sosial dapat ditegakkan dengan sanksi yang dimiliki hukum pidana terhadap seseorang yang berperilaku tidak sesuai dengan norma-norma tersebut.

Kedua, kebijakan penanggulangan aliran sesat dengan menggunakan hukum pidana untuk masa yang akan datang, dapat dilakukan dengan antisipasi yuridis, yaitu mempersiapkan berbagai peraturan yang bersangkut-paut dengan aliran sesat sebagai bagian dari tindak pidana agama, terutama dalam Konsep KUHP.

Kedua, Penanggulangan terhadap aliran sesat melalui upaya non penal dapat ditempuh dengan melakukan pendekatan agama (religion prevention). Di samping itu diperlukan pula pendekatan budaya/kultural, pendekatan moral/edukatif. Atau dengan kata lain, pendekatan agama merupakan salah satu upaya non penal dalam menanggulangi aliran sesat perbedaan pandangan keagamaan/ kepercayaan.

Ketiga, konsepsi kebijakan penanggulangan aliran sesat adalah mengintegrasikan dan mengharmonisasikan kegiatan atau kebijakan non penal dan penal itu ke arah penekanan atau pengurangan faktor-faktor potensial untuk tumbuh dan suburnya aliran sesat di Indonesia. Dengan pendekatan integral inilah diharapkan penanggulangan aliran sesat benar-benar dapat berhasil, sehingga ummat dapat hidup berampingan secara damai dalam menjalankan agama, 
keyakinan, ibadah dan kepercayaannya sebagaimana dicantumkan dalam Undangundang Dasar 1945.

\section{C.2. SARAN}

Sehubungan dengan hasil-hasil penelitian yang dikemukakan di atas, maka beberapa saran yang dapat diajukan adalah sebagai berikut;

1. Kebijakan rasional dalam menanggulangi aliran sesat sebaiknya ditempuh dengan pedekatan/ kebijakan integral, baik dengan menggunakan "penal" maupun dengan sarana "non-penal"

2. Pencegahan terhadap aliran sesat janganlah diperlakukan/dilihat sebagai problem yang terisolir dan ditangani dengan metode yang simplistik dan fragmentair, tetapi seyogya-nya dilihat sebagai masalah yang lebih kompleks dan ditangani dengan kebijakan/tindakan yang luas dan menyeluruh.

3. agar tidak menimbulkan masalah sosial, pencegahan terhadap aliran sesat sepatutnya didasarkan pada penghapusan sebab-sebab dan kondisi-kondisi yang menyebabkan timbulnya kejahatan. Upaya penghapusan sebab-sebab dan kondisi-kondisi yang demikian harus merupakan "strategi pokok/mendasar dalam upaya pencegahan aliran sesat"

4. menjadikan ajaran agama sebagai sumber motivasi, sumber inspirasi, dan sumber evaluasi yang kreatif dalam menanggulangi aliran sesat

5. memfasilitasi perkembangan keberagamaan dalam masyarakat dengan kemajuan bangsa.

6. mencegah konflik sosial antar umat beragama dan meningkatkan ( "meningkatkan kerukunan" ) antar umat bangsa, baik dengan pendekatan kultural maupun keagamaan. 


\section{PUSTAKA}

Ahmad, Kamri Ahmad, Peranan Masyarakat dalam penyelesaian Tindak Pidana Di Sulawesi Selatan, Ringkasan Desertasi, disampaikan pada Rapat Senat Terbatas Ujian Doktor Dalam Ilmu Hukum pada Program Doktor Ilmu Hukum Undip, tanggal 30 Mei 2007

Gilissen, Jhon dan Firts Gorle, Sejarah Hukum Suatu Pengantar, edisi terjemahan, Refika Aditama, Bandung, 2005

Muladi. Politik Hukum Pidana, Dasar Kriminalisasi dan Dekriminalisasi serta Beberapa Perkembangan Asas dalam RUU KUHP. Makalah. Dalam Beberapa tulisan Terkait kebijakan Kriminal dalam RUU KUHP. Bahan Bacaan untuk Focus Group Discussion yang diselenggarakan ELSAM, DRSP (Democratic Reform Support Program) dan Aliansi Nasional Reformasi KUHP dengan tema: "Melihat Politik Kodifikasi dalam Rancangan KUHP". Hotel Ibis Tamrin, Jakarta 28 September 2006

Nawawi Arief, Barda. Kebijakan Legislatif dalam Penanggulangan Kejahatan dengan Pidana Penjara, Badan Penerbit Universitas Dipoegoro, Semarang 1996

Beberapa Aspek Kebijakan Penegakan dan Pengembangan Hukum Pidana, PT. Citra Aditya Bakti, Bandung, 1998

.............................Kebijakan legislatif dalam Penanggulangan Kejahatan dengan Pidana Penjara, Badan Penerbit Universitas Diponegoro.Semarang. 2000

Bunga Rampai Kebijakan Hukum Pidana, Citra Aditya Bakti, Bandung: 2002

Pembaharuan Hukum Pidana Dalam Perspektif Perbandingan, Citra Aditya Bakti, Bandung; 2005

Sistem Pemidanaan Dalam Ketentuan Umum Konsep RUU KUHP 2004, Bahan Sosialisasi RUU KUHP 2004, diselenggarakan oleh Departemen Hukum dan HAM di Hotel Sahid Jakarta, tgl. 23-24 Maret 2005

Kebijakan Kriminalisasi Kumpul Kebo Dan Santet, makalah pada Seminar "Relevansi KUHP Dalam Upaya Penegakan Supremasi Hukum di Indonesia" FH UNUD, 30 April 2005 hal 10-11 
Rahardjo, Satjipto Rahardjo, Pidato mengakhiri masa jabatan sebagai Guru Besar Tetap pada Fakultas Hukum Universitas Diponegoro, 15 Desember 2000

Rasjidi, Lili. Dasar Dasar Filsafat Hukum, Citra Aditya Bakti,Bandung, 1990

Senoadji , Oemar, Hukum (Acara) Pidana Dalam Prospeksi. Erlangga, Jakarta 1976

Soekanto, Soerjono, Faktor-faktor yang Mempengaruhi Penegakan Hukum, PT. Raja Grafindo Perkasa, Cet. III, Jakarta, 1993

Suma, Muh. Amin, Telaah Kritis Sumbangan Konstruktif Terhadap RUU KUHP, Makalah, Disampaikan pada "Sosialisasi Rancangan Undang-Undang Kitab Undang-Undang Hukum Pidana “ diselenggarakan oleh Departemen Kehakiman dan HAM Direktorat Jenderal Peraturan Perundang-undangan Jakarta, 08 September 2004

Wigjosoebroto, Soetandyo, Hukum: Paradigma, Metode dan Dinamika Masalahnya, ELSAM HUMA, Jakarta 2002

Yogaswara, A. Aliran Sesat Dan Nabi-Nabi Palsu, Riwayat Aliran Dan Para Nabi Palsu Di Indonesia, Narasi, Yogyakarta, 2008

Zara, M. Yuanda et al, Aliran-aliran Sesat di Indonesia, Banyu Media, Yogyakarta, 2007

Jawa Pos, Pelarangan Al-Qiyadah. 31 Oktober 2007 hal 4

TEMPO Interaktif, Jakarta 02 November 2007 | 23:45 WIB 